\title{
ОГЛЯДИ
}

УДК 378.048 .02

\section{СУЧАСНІ ТЕНДЕНЦЇ̈ МЕТОДИКИ НАВЧАННЯ ІНОЗЕМНИХ МОВ І КУЛЬТУР: ЗАСТОСУВАННЯ ТЕХНОЛОГІЙ НАВЧАННЯ}

\author{
Микитенко Н. О., Чорна І. Ю. \\ natusiamykyt@gmail.com; iren.ch31262@gmail.com \\ Львівський наиіональний університет імені Івана Франка \\ Дата надходження 02.02.2017. Рекомендовано до друку 26.02.2017.
}

\begin{abstract}
Анотація. Статтю присвячено дослідженню впливу технологій, зокрема "педагогічної технології" i “технології навчання”, на розвиток сучасної методичної науки. Розглянуто сутність понять "педагогічна технологія" і “технологія навчання" відповідно до вітчизняних і зарубіжних досліджень. На основі здійсненого аналізу джерел $з$ проблематики дослідження окреслено типи педагогічних технологій i їх поділ на певні блоки, запропонований ученими-методистами на основі здійснених ними досліджень їхнього власного досвіду. В межах кожного блоку педагогічних технологій виокремлено технології навчання, які забезпечують інтегрований розвиток необхідних мовленнєвих навичок і вмінь у межах одного чи кількох навчальних занять, тим самим забезпечено покрокове досягнення загальної мети виучуваного курсу.

Ключові слова: педагогічна технологія, технологія навчання, методологічні вимоги до педагогічних технологій, класифікація педагогічних технологій і технологій навчання.
\end{abstract}

Микитенко Н. А., Чорна И. Ю. Львовский национальный университет имени Ивана Франко Современные тенденции методики обучения иностранным языкам и культурам: применение технологий обучения

Анотация. Статья посвящена исследованию влияния технологий, в частности “педагогической технологии" и “технологи обучения", на развитие современной методической науки. Рассмотрена сущность понятий “педагогическая технология" и “технология обучения" в соответствии с отечественными и зарубежными исследованиями. На основе проведенного анализа литературы по проблематике исследования определены типы педагогических технологий и их разделение на определенные блоки, предложенные ученымиметодистами на основе проведенного анализа, а также их собственного опыта. В пределах каждого блока педагогических технологий выделены технологии обучения, которые обеспечивают интегрированное развитие необходимых речевых навыков и умений в пределах одного или нескольких учебных занятий, тем самым обеспечено пошаговое достижение общей цели изучаемого курса.

Ключевые слова: педагогическая технология, технология обучения, методологические требования к педагогическим технологиям, классификация педагогических технологий и технологий обучения.

Mykytenko N., Chorna I. Lviv National University named after Ivan Franko

Current tendencies of methodology of teaching foreign languages and cultures: application of teaching technologies

Abstract. The article is devoted to the research of the influence of technologies, in particular, "pedagogical technology" and "studying technology" on the development of modern methodological science. The aim of the article lies in critical analysis of the development of Ukrainian methodological science in the context of the application of effective pedagogical technologies and technologies of teaching foreign languages. Main part of the article reveals the essence of such concepts as "pedagogical technology" and "studying technology" in accordance with Ukrainian and foreign studies. Accomplished research allows to determine "technology" as the technology that widely examines the educational process, taking into account its participants (including age, available knowledge of students), the purpose (desired level of formation of a certain competence) and 
the direction of the training course ("Foreign Language", "Professionaly Oriented Foreign Language or Foreign Language for Specific Purposes", "Business Foreign Language", etc.), tasks, methods and forms of organization of the educational process, management of such a process, problematic aspects of this process, etc. The "studying technology" represents methods, technologies and techniques that are a varied means of achieving the ultimate goal of the course, based on the topic of the lesson, the type of speech activity, a certain competence and the effectiveness of the specific skills and abilities development in the context of the applied learning technology. General results of the research proves that the development of modern methodological science through the prism of technology usage contributes to a number of important issues, such as: improving the teaching and pedagogical activities; developing the creativity of students and lecturers, their copious "dialogue", effective cooperation; high motivation of the participants of educational process, in particular - raising the level of students interest, their active participation in the educational process; the personal growth of lecturers as the experienced professionals in their field and students as creative, initiative and analyticaly thinking prospective professionals.

Key words: "pedagogical technology", "studying technology", methodological requirements of "pedagogical technologies", classification of "pedagogical technologies" and "studying technologies".

Постановка проблеми. Тенденції розвитку сучасної вищої освіти сприяють розширенню тематики наукового пошуку, спрямованого на вдосконалення освітнього процесу, зокрема досягнення кінцевих цілей виучуваної навчальної дисципліни. Серед наукових течій, дотичних до виконання цього завдання, одне з чільних місць посідає методика навчання, зокрема іноземних мов і культур. Становлення методики як науки набуває дедалі більшого розвитку, чому сприяють вдосконалення галузі освіти, інтеграція України до Свропейського простору, оновлені вимоги до підготовки випускника закладу вищої освіти тощо.

Аналіз останніх досліджень і публікацій. Значущий теоретико-практичний доробок у розвиток вітчизняної методичної науки здійснили такі вчені, як О. Б. Бігич, Н. Ф. Бориско, І. П. Задорожна, Л. Я. Зєня, Б. І. Лабінська, Н. В. Майєр, Р. Ю. Мартинова, Н. О. Микитенко, Л. І. Морська, С. Ю. Ніколаєва, О. О. Паршикова, О. П. Петращук, В. М. Плахотник, В. Г. Редько, О. Б. Тарнопольський, В. В. Черниш, Л. М. Черноватий. На окрему увагу заслуговують їхні праці, присвячені сучасним технологіям навчання іноземних мов і культур.

Мета статті - критичний аналіз розвитку української методичної науки, зокрема щодо застосування педагогічних технологій та технологій навчання іноземних мов і культур.

Виклад основного матеріалу. На сучасному етапі розвитку методики науковці тяжіють до застосування сучасних технологій навчання іноземних мов і культур, які оптимізують процес засвоєння азів певної навчальної дисципліни відповідно до наявного у студентів рівня сформованості іншомовної комунікативної компетентності й відведеного часу на досягнення кінцевих цілей навчального курсу (Бистрова, 2015; Бігич, 2017; Бігич та ін., 2012-2014, 2017; Лещенко; Ніколаєва та ін., 2015; . Шило і Савченко, 2014; Klopfer, Osterweil, Groff, \& Haas, 2009; Eady \& Lockyer, 2013). Для успішної реалізації поставлених навчально-методичних завдань дедалі більшої популярності набувають технології навчання, яким учені-методисти довіряють важливу місію - за встановлений відрізок часу досягти відповідного рівня сформованості певної компетентності.

Значна роль у сучасному підході до вибору інструментарію для формування у студентів іншомовної комунікативної компетентності відводиться саме технологіям навчання, які сприяють ефективному й результативному формуванню усіх ії складників (мовних і мовленнєвих, а також лінгвосоціокультурної й навчально-стратегічної компетентностей). Так, для розвитку необхідних мовленнєвих навичок і вмінь у фахово орієнтованому, діловому, академічному письмовому i/чи усному спілкуванні викладач іноземної мови оперує низкою доцільних навчальних технологій певних типів і видів.

Варто зазначити, що поняття “технологія навчання” й “педагогічна технологія” різняться. Так, педагогічна технологія трактується українськими науковцями як комплексне явище, 
яке об'єднує учасників освітнього процесу, засоби й способи його організації, спрямовані на грунтовний аналіз усіх проблемних аспектів цього процесу. Технологія ж навчання зосереджується на засвоєнні певного матеріалу відповідно до тематики предмета й цілей навчальної дисципліни (Лещенко). Окрім цього, педагогічна технологія має відповідати певним принципам, до яких належать:

1) концептуальність - опертя на філософську, дидактичну, психологічну, соціальнопедагогічну концепцію досягнення освітньої мети;

2) системність - комплекс методів, форм, прийомів, засобів, тісно переплетених у логічному перебігу освітнього процесу й спрямованих на його цілісність;

3) варіативність застосування засобів і методів для поетапного, планованого, спроектованого формування певного різновиду компетентності й коригування результатів (наприклад посилене вивчення проблемних аспектів певної дисципліни з опертям на загальні результати студентів);

4) ефективність - оптимальне співвідношення часу, обсягу матеріалу й особливостей його змісту для досягнення певного рівня знань студентів;

5) відтворюваність - використання / відтворення обраної педагогічної технології в контексті формування більш, ніж однієї компетентності з різних галузей освіти;

6) візуалізація (застосовується при виборі окремих технологій) - використання аудіо-/ відеотехніки, мультимедійних, автентичних матеріалів тощо (Шило і Савченко, 2014, с. 10).

Технології навчання витлумачуються як послідовності науково обгрунтованих дій викладача зі студентом відповідно до засад певного методу навчання (Ніколаєва та ін., 2015, с. 13). Контекстом класифікації технологій навчання іноземних мов і культур обрано сучасні педагогічні технології навчання, типологізовані за такими критеріями:

1) гуманно-особистісна орієнтація процесу навчання;

2) активізація й інтенсифікація діяльності студентів;

3) ефективність управління й організації освітнього процесу;

4) дидактичне вдосконалення й реконструювання навчального матеріалу;

5) альтернативні педагогічні технології (Ніколаєва та ін., 2015, с. 13).

У межах кожного типу педагогічних технологій навчання виокремлюються види технологій навчання іноземних мов і культур. Так, педагогічні технології на засадах активізації й інтенсифікації діяльності студентів представлено ігровими технологіями, технологіями обговорення дискусійних питань, технологіями проблемного / проектного / інтенсивного навчання, технологіями навчання з використанням опор. Педагогічні технології на засадах ефективності управління й організації освітнього процесу містять технології комп'ютерного / диференційованого / групового / індивідуалізованого навчання, інформаційно-комунікаційні технології, технології “case study" i “портфоліо”. Педагогічні технології на засадах дидактичного вдосконалення й реконструювання навчального матеріалу передбачають технології “діалог культур" і технології інтегрованого / модульного / концентрованого навчання (Ніколаєва та ін., 2015, с. 13).

Доволі конструктивною вважаємо зорієнтовану на студента класифікацію технологій навчання, запропоновану Ю. В. Бистровою (2015). 3-поміж сучасних технологій навчання дослідниця виокремлює ті, які головним суб'єктом навчання позиціонують студента: особистісно орієнтовані; інтеграційні; колективної дії; інформаційні; дистанційні; творчокреативні; модульно-розвивальні технології (Бистрова, 2015, с. 28). Перелічені технології навчання реалізуються в межах педагогічних технологій, які науковець пропонує класифікувати в такий спосіб:

- структурно-логічні педагогічні технології - грунтуються на поетапній логічній організації освітнього процесу з урахуванням діагностики й аналізу результатів;

- інтеграційні педагогічні технології - охоплюють сукупність різноманітних видів діяльності 
й сприяють інтеграції міжпредметних знань;

- професійно-ділові ігрові педагогічні технології-в основі лежать ігрові методи навчання, спрямовані на вирішення компромісного / конфліктного завдання;

- тренінгові технології-засоби - передбачають використання алгоритмів, зокрема комп'ютерних, для розв'язання практичних завдань;

- інформаційно-комп'ютерні технології-засоби - грунтуються на використанні розмаїття комп'ютерних програм на засадах співпраці студента з технічним забезпеченням;

- діалогово-комунікаційні технології - залучають діалогові методи й форми навчання на засадах комунікативної співпраці студентів (Бистрова, 2015, с. 28).

Отже, поняття “педагогічна технологія" і “технологія навчання" корелюють у такий спосіб:

- “педагогічна технологія" дещо ширше розглядає освітній процес, беручи до уваги його учасників (вік, наявні знання студентів), мету (бажаний рівень сформованості певної компетентності) й спрямування навчальної дисципліни (“Іноземна мова”, “Іноземна мова професійного спрямування”, “Ділова іноземна мова” тощо), завдання, способи й форми організації освітнього процесу, управління ним, проблемні аспекти цього процесу тощо;

- “технологія навчання”, представляючи підходи й методи навчання, реалізується через навчальні прийоми викладача іноземної мови, які $€$ варійованими засобами досягнення кінцевих цілей $з$ опертям на тематику заняття, вид мовленнєвої діяльності, певну компетентність, ефективність формування конкретних навичок і розвитку вмінь тощо.

Алегорично окреслюючи ці вагомі поняття методичної науки, "педагогічну технологію" можна порівняти з описом навчальної дисципліни "Іноземна мова", в той час як "технології навчання" належить почесне місце в робочій програмі чи семестровому плані. Відтак, існування одного без іншого унеможливлює злагодженість освітнього процесу.

Ми поділяємо точку зору О. Б. Бігич, що кожен із сучасних підходів до формування іншомовної комунікативної, зокрема професійно орієнтованої, компетентності передбачає використання найефективнішої технології навчання відповідного спрямування. Так, культурологічний підхід до формування іншомовної комунікативної компетентності реалізується засобами технології “діалог культур” (Бігич, 2017a), професійно орієнтований підхід (Бігич та ін., 2013) - засобами комп'ютерного навчання на кшталт авторських навчальних комп'ютерних програм, розроблюваних викладачами іноземних мов (Бігич та ін., 2012), особистісно-діяльнісний підхід (Бігич, 2017b), - засобами технологій індивідуалізованого й диференційованого навчання тощо.

Особистісно-діяльнісний підхід слугував контекстом науково-методичного дослідження сучасного студента як активного суб'єкта іншомовної освіти: майбутнього вчителя й викладача іноземних мов, майбутнього перекладача, а також майбутніх лікарів, логістів, митників і менеджерів туризму в процесі формування конкретного різновиду іншомовної комунікативної, зокрема професійно орієнтованої, компетентності (Бігич та ін., 2014). Так, з метою формування у майбутніх учителів англійської мови компетентності в письмі М. С. Глазунов пропонуе використовувати технології Веб 2.0 (Бігич та ін., 2013, сс. 87-95).

Отже, внаслідок здійсненого аналізу джерел ми дійшли висновку, що серед науковців не існує єдиного підходу до визначення поняття “технологія навчання” - ними запропоновано авторські визначення цього поняття. Однак, інтегруючи всі ключові характеристики феномену технології навчання, ми вважаємо, що ії підгрунтя складають забезпечення креативних, дотичних до поставленої мети способів іії досягнення; вибір методів, форм і прийомів інтегрованого розвитку, необхідних для формування певного різновиду компетентності; вдосконалення предметних і ключових компетентностей; розвиток особистісних якостей студентів (аналітичного мислення, самостійності прийняття рішень при вирішенні конфліктних / повсякденних ситуацій).

Здійснений аналіз дотичних до досліджуваної проблеми вітчизняних і зарубіжних джерел, 
зокрема популярних у наукових колах методичної науки колективних монографій “Електронні засоби навчання іноземних мов студентів: досвід розробки й апробації” (Бігич та ін., 2012), “Сучасний студент у контексті особистісно-діяльнісного підходу: за результатами науковометодичних досліджень” (Бігич та ін., 2014), “Теорія і практика формування професійно орієнтованої іншомовної компетентності в говорінні у студентів нелінгвістичних спеціальностей” (Бігич та ін., 2013), співавторами яких є вітчизняні методисти-науковці - викладачі іноземної мови як профільної і непрофільної навчальної дисципліни, підтверджує особливу актуальність педагогічних технологій і технологій навчання на сучасному етапі розвитку методики навчання іноземних мов і культур. На особливу увагу заслуговують колективні монографії “Сучасні технології навчання іноземних мов і культур у загальноосвітніх й вищих навчальних закладах" (Ніколаєва та ін., 2015) і “Кейсова і подкаст технологї формування міжкультурної компетентності” (Бігич та ін., 2017), безпосередньо пов’язані з предметом нашого дослідження.

Саме технологіям навчання як складника системи навчання іноземних мов і культур притаманна чітка спрямованість на цілі формування іншомовної комунікативної компетентності й наявність засобів для досягнення високого рівня iï сформованості. Останні варіюються відповідно до тематики навчального заняття, його мети й завдань, освітніх потреб цільової аудиторії (з урахуванням віку здобувачів освіти, їхнього самоусвідомлення, досвіду й наявного рівня сформованості знань, навичок і вмінь як складників іншомовної комунікативної компетентності), а також корелюють із особливостями навчального матеріалу. Так, до сучасних засобів формування у майбутніх учителів і викладачів іспанської мови лінгвосоціокультурної компетентності О. Б. Бігич (2017а) відносить автентичні освітні сайти, мультимедійні наочні посібники й сінквейни-колажі, електронні / мобільні кейси (сс. 58-82), міжкультурної компетентності - професійні блоги викладачів й подкасти (Бігич та ін., 2017, сc. 151-156).

Висновок. Таким чином, використання сучасних технологій навчання іноземних мов і культур як складника системи сучасної методичної науки сприяє реалізації таких вагомих аспектів вищої освіти: вдосконаленню навчально-педагогічної діяльності; розвитку креативності викладачів і студентів; їхньому плідному діалогу; ефективній співпраці; високій вмотивованості, зокрема підвищенню рівня зацікавленості студентів, їхній активній участі у навчальнопізнавальному процесі; особистісному зростанню викладачів як досвідчених фахівців і студентів як аналітично мислячих, креативних й ініціативних майбутніх фахівців.

Наша стаття не вичерпує усіх аспектів порушеної наукової проблеми. Подальші перспективи досліджень вбачаємо в докладнішому аналізі кожної педагогічної і навчальної технології з експериментальною підтримкою й опертям на досвід викладання у закладах вищої освіти.

\section{ЛІТЕРАТУРА}

Бистрова, Ю. В. (2015). Інноваційні методи навчання у вищій школі України. Право та інновачійне суспільство, 1(4), 27-33. Взято 3: http://apir.org.ua/wp-content/uploads/2015/ 04/Bystrova.pdf

Бігич, О. Б. (2017а). Методична скарбничка вчителя / викладача іспанської мови: формування лінгвосоиіокультурної компетентності [монографія]. Київ, Україна: Вид. центр КНЛУ.

Бігич, О. Б. (2017b). Сучасні технології навчання іноземних мов і культур : Презентації виступів 21 квітня 2017 року на Всеукраїнській науково-практичній конференції “Іншомовна підготовка працівників правоохоронних органів та сектору безпеки” та 08 грудня 2017 на III міжнародній науково-практичній конференції “Актуальні проблеми іноземної філології та освітній соціокультурний процес”. Взято з: http://bigich.knlu.edu.ua/Conferences.htm

Бігич, О. Б., Бондар, Л. В., Волошинова, М. М., Максименко Л. О., Огуй О. М., Окопна, Я. В., Сімкова, І. О. (2013). Теорія і практика формування професійно орієнтованої іншомовної компетентності в говорінні у студентів нелінгвістичних спеціальностей [колективна монографія]. Київ, Україна: Вид. центр КНЛУ. 
Бігич, О. Б., Васильєва, Е. В., Волошинова, М. М., Глазунов, М. С., Майєр, Н. В., Мацнєва, О. А., ... Ярошенко, О. В. (2014). Сучасний студент у контексті особистісно-діяльнісного підходу: за результатами науково-методичних досліджень [колективна монографія]. Київ, Україна: Вид. центр КНЛУ.

Бігич, О. Б., Волошинова, М. М., Мацнєва, О. А., Метьолкіна, О. М., Кириченко, Т. Г., Ткоробейнікова, Т. І., Окопна, Я. В., Руснак, Д. А. (2012). Електронні засоби навчання іноземних мов студентів: досвід розробки й апробації [колективна монографія]. Київ, Україна: Вид. центр КНЛУ.

Бігич, О. Б., Ігнатенко, В. Д., Коробейнікова, Т. І., Руснак, Д. А., Стрілець, В. В., Ярошенко, О. В. (2017). Кейсова й подкаст технологї формування міжкультурної компетентності [колективна монографія]. Київ, Україна: Вид. центр КНЛУ.

Лещенко, Т. О. Нові технологї вивчення предмета "Українська мова за професійним спрямуванням” студентами стоматологічного факультету. Взято 3: http://elib.umsa.edu.ua/ jspui/bitstream/umsa/2086/1/Novi_.pdf

Ніколаєва, С. Ю., Борецька, Г. Е., Майєр, Н. В., Устименко, О. М., Черниш, В. В. (2015). Сучасні технологї навчання іноземних мов і культур у загальноосвітніх й вищих навчальних закладах [колективна монографія]. Київ, Україна: Ленвіт.

Шило, С. І. і Савченко, Т. В. (2014). Удосконалення навчально-виховного прочесу на основі впровадження інновачійних технологій як засіб розвитку творчої особистості учасників педагогічного процесу. Взято 3: http://virtkafedra.ucoz.ua/imidg/shilo.pdf

Eady, M. J. \& Lockyer, L. (2013). Tools for learning: technology and teaching strategies. Retrieved from http://ro.uow.edu.au/cgi/viewcontent.cgi?article=1413\&context=asdpapers

Klopfer, E., Osterweil, S., Groff, J. \& Haas, J. (2009). Using the Technology of Today, in the Classroom Today. Retrieved from http://education.mit.edu/wp-content/uploads/2015/01/ GamesSimsSocNets_EdArcade.pdf

\section{REFERENCES}

Bystrova, Yu. V. (2015). Innovatsijni metody navchannia u vyschij shkoli Ukrainy. Pravo ta innovatsijne suspil'stvo, 1(4), 27-33. Vziato z: http://apir.org.ua/wp-content/uploads/2015/04/Bystrova.pdf

Bihych, O. B. (2017a). Metodychna skarbnychka vchytelia / vykladacha ispans'koi movy: formuvannia linhvosotsiokul'turnoi kompetentnosti [monohrafiia]. Kyiv, Ukraina: Vyd. tsentr KNLU.

Bihych, O. B. (2017b). Suchasni tekhnolohii navchannia inozemnykh mov i kul'tur: Prezentatsii vystupiv 21 kvitnia 2017 roku na Vseukrains'kij naukovo-praktychnij konferentsii "Inshomovna pidhotovka pratsivnykiv pravookhoronnykh orhaniv ta sektoru bezpeky" ta 08 hrudnia 2017 na III mizhnarodnij naukovo-praktychnij konferentsii "Aktual'ni problemy inozemnoi filolohii ta osvitnij sotsiokul'turnyj protses”. Vziato z: http://bigich.knlu.edu.ua/Conferences.htm

Bihych, O. B., Bondar, L. V., Voloshynova, M. M., Maksymenko L. O., Ohuj O. M., Okopna, Ya. V.,

Simkova, I. O. (2013). Teoriia i praktyka formuvannia profesijno oriientovanoi inshomovnoi kompetentnosti v hovorinni u studentiv nelinhvistychnykh spetsial'nostej [kolektyvna monohrafiia]. Kyiv, Ukraina: Vyd. tsentr KNLU.

Bihych, O. B., Vasyl'ieva, E. V., Voloshynova, M. M., Hlazunov, M. S., Majier, N. V., Matsnieva, O. A., ... Yaroshenko, O. V. (2014). Suchasnyj student u konteksti osobystisno-diial'nisnoho pidkhodu: za rezul'tatamy naukovo-metodychnykh doslidzhen' [kolektyvna monohrafiia]. Kyiv, Ukraina: Vyd. tsentr KNLU.

Bihych, O. B., Voloshynova, M. M., Matsnieva, O. A., Met'olkina, O. M., Kyrychenko, T. H., Tkorobejnikova, T. I., Okopna, Ya. V., Rusnak, D. A. (2012). Elektronni zasoby navchannia inozemnykh mov studentiv: dosvid rozrobky j aprobatsii [kolektyvna monohrafiia]. Kyiv, Ukraina: Vyd. tsentr KNLU. 
Bihych, O. B., Ihnatenko, V. D., Korobejnikova, T. I., Rusnak, D. A., Strilets', V. V., Yaroshenko, O. V. (2017). Kejsova j podkast tekhnolohii formuvannia mizhkul'turnoi kompetentnosti [kolektyvna monohrafiia]. Kyiv, Ukraina: Vyd. tsentr KNLU.

Leschenko, T. O. Novi tekhnolohii vyvchennia predmeta "Ukrains'ka mova za profesijnym spriamuvanniam" studentamy stomatolohichnoho fakul'tetu. Vziato z: http://elib.umsa.edu.ua/jspui/ bitstream/ umsa/2086/1/Novi_.pdf

Nikolaieva, S. Yu., Borets'ka, H. E., Majier, N. V., Ustymenko, O. M., Chernysh, V. V. (2015). Suchasni tekhnolohii navchannia inozemnykh mov i kul'tur u zahal'noosvitnikh j vyschykh navchal'nykh zakladakh [kolektyvna monohrafiia]. Kyiv, Ukraina: Lenvit.

Shylo, S. I., Savchenko, T. V. (2014). Udoskonalennia navchal'no-vykhovnoho protsesu na osnovi vprovadzhennia innovatsijnykh tekhnolohij iak zasib rozvytku tvorchoi osobystosti uchasnykiv pedahohichnoho protsesu. Vziato z: http://virtkafedra.ucoz.ua/imidg/shilo.pdf

Eady, M. J. \& Lockyer, L. (2013). Tools for learning: technology and teaching strategies. Retrieved from http://ro.uow.edu.au/cgi/viewcontent.cgi?article=1413\&context=asdpapers

Klopfer, E., Osterweil, S., Groff, J. \& Haas, J. (2009). Using the Technology of Today, in the Classroom Today. Retrieved from http://education.mit.edu/wp-content/uploads/2015/01/ GamesSimsSocNets_EdArcade.pdf 